\title{
Om te teologiseer oor God en lyding: \\ Opmerkings na aanleiding van Harold Kushner \\ se interpretasie van Job 40:9-14
}

I J J Spangenberg

Universiteit van Suid-Afrika

\begin{abstract}
To reflect theologically on God and suffering: Remarks relating to Harold Kushner's interpretation of Job 40:9-14

More than a decade ago rabbi Harold Kushner wrote a bestseller on God and suffering, entitled When bad things happen to good people. Even Christian theologians took cognizance of it. Kushner based his ideas on a dubious interpretation of Job 40:9-14. According to this interpretation, God confesses his inability to control evil at all times. Although this interpretation can be questioned the reflections are stimulating. Kushner's book is a clear indication of how theological reflection comes about. Theological statements do not flow directly from the Tanakh or from the Christian Bible. As ancient Near Eastem religious documents they only serve as catalysts for our own theological reflections.
\end{abstract}

\section{INLEIDING}

Harold Kushner, 'n rabbi van die Verenigde State van Amerika, het 'n aantal jare gelede 'n boek gepubliseer met die titel When bad things happen to good people $(1982)^{1}$. Die feit dat sy veertienjarige seun aan progeria (snelle veroudering) dood is, het aanleiding gegee tot die skryf daarvan. Die boek het spoedig 'n blitsverkoper geword wat al in verskeie tale vertaal is (o a in Afrikaans met die power titel $M y$ ongelukskind [Kushner 1983b]) $)^{2}$. Een van die redes vir die populariteit daarvan is geleë in die 'nuwe antwoord' wat die boek bied op die ou vraag na God se betrokkenheid by rampe, ellendes, siekte en lyding. Alhoewel Kushner die boek vir Jan/ San Alleman geskryf het, kon teoloë nie anders nie as om daarvan kennis te neem (vgl o a Schillebeeckx 1987, Häring 1987, Goedhart 1990), want dit het idees waar-

\footnotetext{
- 'n Verwerkte weergawe van 'n referaat wat gelewer is op 18 Oktober 1991 tydens 'n departementele seminaar van die Departement Ou Testament aan die Universiteit van Suid-Afrika.
} 
waarmee hulle bekend is en wat hulle onder mekaar uitruil, verpopulariseer (Cooper 1991:291). In hierdie artikel wil ek sy hantering van die boek Job onder die loep neem omdat hy sy siening oor God se betrokkenheid by rampe, ellendes, siekte en lyding grootliks daarop bou. Sy gebruik van 'n Ou-Testamentiese teks om oor die magteloosheid van God te skryf, het na my mening iets vir ons te sê oor ons teologiese gesprekke en nadenke oor God en lyding asook oor die lydende God.

\section{GOD EN LYDING: POPULARE VERKI ARINGS 3}

Kushner behandel in die eerste hoofstuk van sy boek (1982:14-38) 'n aantal populêre verklarings wat mense bied op die vraag waarom goeie mense dikwels die slegte ervaar. Een van die mees populêre verklarings is die een wat uitgaan van die beginsel van beloning en straf (of oorsaak en gevolg [Du Toit 1990:4]). Daar is mos nie verniet 'n spreekwoord wat lui 'boontjie kry sy loontjie' nie. Hierdie antwoord slaag egter nie daarin om mense sin in hulle lyding te laat beleef nie. Om die waarheid te sè, dit maak eerder skuldgevoelens wakker as wat dit troos bied (Kushner 1982:18).

Dikwels troos mense hulleself met die gedagte dat God in beheer is en dat $\mathrm{Hy}$ wel weet waarom mense 'onregverdig' moet ly. $H y$ is in beheer van die geskiedenis en stuur alles af op 'n voortreflike einddoel. Vir alles wat gebeur in hierdie wêreld is daar dus 'n goeie rede voor, ons insig is net te beperk om die rede te kan insien ${ }^{4}$. Dit is soos 'n pragtige tapisserie waarvan ons maar slegs die agterkant met die warboel van gare en knope raaksien. Tereg wys Kushner daarop dat ons hierdie standpunt (die doel heilig die middel) onaanvaarbaar sal vind wanneer mense hulle wreedhede teenoor ander op so 'n wyse probeer regverdig - hoeveel te meer geld dit dan nie ten opsigte van God nie (Kushner 1982:27).

Nog 'n populêre antwoord is dat God lyding gebruik om ons iets te leer of om beter mense (meer simpatieke mense) van ons te maak. Lyding het dus 'n hoër doel (vgl Du Toit 1990:5). Hierdie verklaring het sowel Ou- as Nuwe-Testamentiese grond onder die voet (vgl Spr 3:11-12; Heb 12:4-12). Net soos ouers hulle kinders tug, moet God ons ook soms vir ons beswil tug. 'n Beswaar wat teen hierdie verklaring ingebring kan word, is dat 'n drag slae sonder 'n verduidelikende antwoord weinig opvoedkundige waarde het (Kushner 1982:31-32).

Soms hoor 'n mens na die afsterwe van geliefdes die verklaring dat God hulle die pyn en lyding van hierdie wêreld gespaar het deur hulle na 'n beter oord (die hemel) te ontruk. Volgens Kushner (1982:35-37) getuig hierdie verklaring nie van begrip vir die hartseer en pyn van diegene wat die geliefde verloor het nie. Voorts, weet ons ook nie verseker dat daar wél 'n beter oord is nie. Dit is iets waarop ons hoop. Hierdie hoop mag egter nie maak dat ons onreg en kwaad aan hierdie kant van die graf deur die vingers sien nie. 
Die bostaande verklarings het die volgende met mekaar in gemeen: hulle hou God voor as die oorsaak van lyding en probeer sy optrede regverdig. Ons het hier dus met tipiese teodiseë te doen. Maar, vra Kushner dan aan die einde van die hoofstuk, is daar nie moontlik 'n ander verklaringsmodel wat God nie as die oorsaak van lyding voorhou nie? Kan daar dinge in hierdie wêreld gebeur wat nie deur God gewil is nie? Vir die beantwoording van hierdie vrae wend hy hom dan tot die boek Job omdat die boek ' $n$ indringende bespreking van menslike lyding bied.

\section{KUSHNER SE INTERPRETASIE VAN JOB 40:9-145}

Kushner aanvaar, soos verskeie ander geleerdes, dat die skrywer van die boek Job 'n ou volksverhaal gebruik het as basis vir sy boek (vgl Müller [1978:23-48] se bespreking van die standpunte hieroor). Die sedeles wat die ou verhaal (gekonstrueer uit die proloog en epiloog van die boek Job) verkondig, is: moenie jou geloof in God prysgee wanneer jy swaar tye beleef nie. God weet wat Hy doen en as jy volhard in jou geloof, sal jy beloon word (Kushner 1982:41). Die skrywer van die boek Job kon nie vrede maak met hierdie sedeles nie en het die ou verhaal as ' $t$ ware omgekeer sodat die karakters net mooi die teenoorgestelde rolle beklee as in die ou verhaal. Job berus nie soos vroeër maar net in sy lot nie, maar kla God selfs aan, terwyl die vriende wat kom simpatiseer het, nou die tradisionele standpunt verkondig, naamlik dat God goeie mense beloon en slegte mense straf. Na die drie siklusse van gesprekke (Job 3-27) bereik die boek 'n klimaks wanneer Job God daag om bewyse vir sy oortredinge waarvoor hy gestraf word, voor te le of om die saak teen hom terug te trek (Job 29-31). In reaksie hierop antwoord God Job dan uit 'n storm (Job 38-41), maar sy antwoord is in werklikheid nie 'n antwoord nie. Hy reageer nie op Job se uitdaging dat $\mathrm{Hy}$ bewyse moet indien nie, ook bied $\mathrm{Hy}$ geen verklaring waarom Job soveel moes ly nie. Inteendeel, Hy loop Job trompop met die vraag: Wie is jy om my bestuur van die wêreld te bevraagteken? Op die klank af klink hierdie antwoord maar net na nog ' $n$ verdediging van die vergeldingsdogma. Kushner is egter van mening dat mense God se antwoord en dus die antwoord wat die boek op 'onregverdige' lyding bied, nie reg begryp nie.

Volgens hom sal enige (godsdienstige) leser van die boek Job die volgende drie stellings wil onderskryf (Kushner 1982:45):

- God is almagtig en verantwoordelik vir alles wat in die wêreld gebeur. Niks kan gebeur as $\mathrm{Hy}$ dit nie gewil het nie.

- God is reguerdig en goed en sorg dat goeie mense beloon en slegte mense gestraf word.

- Job is 'n goeie mens. 
Toe dit goed gegaan het met Job, kon enigeen aldrie stellings onderskryf, maar Job se lyding dwing jou om een van die drie prys te moet gee. As God almagtig en regverdig is, moes Job kwaad gedoen het om soveel lyding te verdien het. (Dit was die vriende se verklaring; vgl o a Job 4:8; 8:4-7). As Job die regte pad bewandel het, maar ten spyte daarvan ellendes beleef het en God is almagtig en verantwoordelik vir wat in die wêreld gebeur, is Hy nie regverdig en goed nie. (Dit was Job se verklaring vir sy lyding; vgl o a Job 9:20-24). As God regverdig en goed is en Job beloon moes word, maar God dit nie kon doen nie (al sou Hy hoe graag wou) dan is Hy nie almagtig nie. Dit is volgens Kushner die skrywer van die boek Job se antwoord. Volgens hom word hierdie antwoord mooi verwoord in Job 40:9-14 wat hy soos volg vertaal (Kushner 1982:51):

Het jy 'n arm soos God?

Kan jy donder met 'n stem soos syne?

Werp $j y$ die goddelose dan neer waar hulle staan, begrawe hulle saam in die stof ... dan sal Ek jou loof omdat jou regterhand jou oorwinning laat behaal.

(Kushner 1982:51)

Wat God hier vir Job sê, kan soos volg saamgevat word: 'As jy dink dit is maklik om die wêreld te bestuur en te verhinder dat mense onregverdig ly, kom neem gerus dan oor' (Kushner 1982:51). God wil dat mense geluk en vrede beleef, maar soms staan ook Hy magteloos teenoor die kwaad wat in die wêreld gebeur. Die beskrywing van sy worsteling met die seemonster (Leviatan) ${ }^{6}$ in Job $40-41$ is 'n bewys dat Hy dit soms moeilik vind om die chaos te beteuel. Wanneer onskuldige mense dus rampe en ellendes beleef, is dit nie 'n teken dat God hulle straf nie. Volgens Kushner (1982:51) moet ons afsien van die gedagte dat God die bewerker van rampe en ellendes in hierdie wêreld is. Mense huiwer soms om hierdie gedagte te aanvaar en hulle voel ontredderd en losgesny van hulle godsdienstige ankers, want hulle is groot gemaak met die gedagte dat alles wat in hierdie wêreld gebeur deur God gewil is, maar diegene wat die gedagte aanvaar het, beleef 'n stuk bevryding. Dit is sinloos om soos Job te vra: 'God, waarom doen U dit aan my?' Ons moet liewer sê: 'God, aanskou my ellende en staan my by!' Ons kan kwaad word vir wat oor ons pad gekom het, maar ons hoef nie God daarvoor te blameer nie. Ook behoort nie onsself te kasty met die gedagte dat as ons maar net beter geleef het, God ons nie sou gestraf het nie.

Kushner het met die skryf van die boek dus probeer om te breek met die gedagte dat alles wat in hierdie wèreld gebeur deur God gewil is. Voorts wou hy ook mense daartoe bring om te breek met die gedagte dat pyn en lyding, siekte en dood, rampe en ellendes die gevolg van God se straf op hulle wandade is. Dwarsdeur sy boek beklemtoon hy die feit dat God nie teenoor die lyer staan nie, maar langs hom. 


\section{TENDENSE IN RESENIE BESINNINGS OOR GOD EN LYDNG}

Die feit dat Kushner se boek 'n blitsverkoper geword het, kan 'n mens maklik verlei om te dink dat hy 'n nuwe antwoord op die ou vraag na God se betrokkenheid by lyding verwoord het. Wie egter vertroud is met Christen- en Joodse teoloë se besinnings ná die Tweede Wêreldoorlog oor God se betrokkenheid by lyding, sal besef dat sy idees nie heeltemal uniek is nie (vgl Cooper 1991:300; Küng 1992:584-609). Vanhoutte (1988:275) identifiseer byvoorbeeld twee tendense in resente publikasies oor die lydingsvraagstu', naamlik 'n tendens tot polarisering of skeiding van God en lyding en ' $n$ tendens tot verknoping van God en lyding. Die eerste tendens kom daarin tot uitdrukking dat teoloë God nie (meer) as die oorsprong van lyding beskou nie en uitdruklik verklaar dat $\mathrm{Hy}$ dit nie wil nie, terwyl die tweede tendens daarin tot uitdrukking kom dat teoloë beklemtoon dat God nie onbetrokke ons lyding gade slaan nie, maar met ons meely en ons help om dit te verwerk. Lyding word nie meer beskou as iets wat net mense beleef nie. Die leerstelling aangaande God se impassibiliteit word tans nie meer algemeen onderskryf nie.

Die twee tendense wat Vanhoutte uitwys, is inderdaad aanwesig in Kushner se boek daarom hoor ons hom sê: 'I don't believe that an earthquake that kills thousands of innocent victims without reason is an act of God' (Kushner 1982:67) en 'The act of God is the courage of the people to rebuild their lives after the earthquake, and the rush of others to help them in whatever way they can. If a bridge collapses, if a dam breaks, if a wing falls off an airplane and people die, I cannot see that as God's doing' (Kushner 1982:68).

Kushner het die impulse vir sy standpunt in die boek Job (en dan spesifiek Job 40:9-14) gevind, maar selfs sy interpretasie van dié gedeelte is nie uniek nie. In dieselfde jaar waarin sy boek verskyn het, het Athalya Brenner 'n artikel oor God se antwoord aan Job gepubliseer waarin sy die stelling maak dat $\mathrm{Hy}$ in Job 40:7-14 sy eie onvermoë bely om die kwaad te beteuel en goddeloses telkens die onderspit te laat delf (Brenner 1981:133-134). Maar Kushner het waarskynlik nie by Brenner kers opgesteek nie, maar by Sheldon Blank en Matitiahu Tsevat. Blank het in 1955 'n artikel gepubliseer waarin hy 'n saak uitmaak dat die Ou Testament 'n aantal kere gewag maak van God se lyding. Een van die gedeeltes waarin hy hierdie gedagte vind, is Job 40:9-14. Volgens hom erken God hier teenoor Job dat die bestuur van die wêreld nie 'n maklike taak is nie en dat dit Hom menige keer pyn en lyding besorg (Blank 1955:35-36). Van Tsevat (1980:36) het Kushner moontlik die 'klassieke trilemma' (die stellings oor God se almag en regverdigheid, en Job se onskuld) ontleen. 


\section{5. 'N KORT BESPREKING VAN JOB 40:9-14}

Verskeie sistematiese en praktiese teoloë het al gereageer op Kushner se bydrae tot die gesprek oor God en lyding, maar geen Ou-Testamentikus het al (na my wete) sy interpretasie van Job 40:9-14 beoordeel nie. Alvorens ek eersgenoemde teoloë aan die woord stel en self ook een en ander oor sy bydrae sê, sou ek graag sy interpretasie van hierdie gedeelte onder die loep wou neem.

Neem ons die Masoretiese teks as uitgangspunt, vorm hierdie verse deel van die tweede Jahwerede wat met Job 40:6 begin. Verskeie geleerdes (vgl o a Marcus 1949:28; Rowley 1970:327; Tsevat 1980:12-19) is egter van mening dat Job 40:7-14 oorspronklik die slot van die eerste en enigste Jahwerede was wat gestrek het vanaf Job 38:1-40:14. Die gedeeltes oor die seekoei (Behemot; Job 40:15-24) en die krokodil (Leviatan; Job 40:25-41:26) is latere toevoegings. So gesien, vorm hierdie verse (Job 40:9-14) dan die klimaks van Jahwe se antwoord aan Job. Ek is geneig om met hierdie geleerdes saam te stem, want alhoewel daar 'n mate van ooreenkoms tussen die eerste en die tweede Jahwerede is, ${ }^{7}$ staan hierdie verse in die huidige konteks ietwat los van dit wat daarop volg. Voorts kry ons ook hier met 'n aantal retoriese vrae te doen (vgl Job 40:9) soortgelyk aan dié in die voorafgaande Jahwerede.

Kushner het, na my mening, stewige grond onder sy voete wanneer hy hierdie verse beskou as 'n samevatting van Jahwe se antwoord aan Job. Sy vertaling en interpretasie daarvan laat egter te wense oor. Volgens hom rig God 'n uitdaging aan Job om dit te doen waartoe Hyself nie in staat is nie, naamlik om die kwaad te beteuel. Hierdie verse getuig dus (volgens hom) van God se onmag. Na my mening is die teendeel egter waar. Hierdie verse spreek van God se mag en Job se onmag. Die gedeelte behoort soos volg vertaal te word:

$7 \quad$ Omgord jou heupe soos 'n man.

Ek sal jou ondervra en jy moet My antwoord!

$8 \quad$ Wil jy werklik My reg verbreek;

My tot 'n leuenaar maak sodat jy reg kan wees?

$9 \quad$ Het jy 'n arm soos God?

Kan jy donder met 'n stem soos Hy?

10 Oordek jou met trots en verhewenheid.

Beklee jou met eer en heerlikheid.

11 Laat jou woede ontvlam.

Gluur die hoogmoedige aan en verneder hom. 
12 Gluur eike hoogmoedige aan en laat hom die onderspit delf. Vertrap die goddeloses waar hulle staan.

13 Verberg hulle saam in die stof.

Sluit hulle toe in die onderwêreld.

14 Dan sal Ek jou loof, omdat jou regterhand jou laat oorwin.

Hierdie gedeelte verwoord God se reaksie op die klagstaat wat Job ingedien het. Sy klagstaat behels dat God Hom skuldig maak aan wanbestuur van sy skepping (vgl o a Job 30:18-23). Hy beloon nie die regverdiges en straf ook nie die goddeloses nie, maar laat mense onregverdig ly. God se eerste reaksie hierop is om Job bewus te maak dat hy (Job) die reg verdraai ( $(\mathrm{8})$. Hy is besig om presies dit te doen waarvan hy God beskuldig. Hy maak God tot ' $n$ leuenaar. Hy beskuldig Hom van onregverdige optrede. Omdat Job nit tot inkeer wil kom nie, is God bereid om met die spel voort te gaan en daag Job dan uit om sy rol oor te neem. Die retoriese vrae in vers 9 suggereer egter die uitslag van hierdie rolbesetting. Job besit nie die mag wat God besit nie en gaan misluk. Hy kan self nie dit doen wat hy verwag God moet doen nie, naamlik om die goddeloses die onderspit te laat delf (vgl Loader 1983 se bespreking hiervan). Sou Job dit kon doen, is God bereid om sy rol oor te neem en hom (Job) dan te loof en te prys. In reaksie hierop kom Job dan met die belydenis dat hy 'n liggewig is (Job 40:3-5). Wat aan die einde blyk, is God se mag en Job se onmag. God is by magte om dit te doen wat Job van Hom vra, naamlik om die oormoediges te verneder. Die vraag waarom Hy dit nie in Job se geval doen nie, word egter onbeantwoord gelaat.

\section{KOM ALIES UIT GOD SE HAND?}

Die boek Job bied dus nie die antwoord op lyding wat Kushner daarin meen te vind nie, naamlik dat God magteloos staan teenoor die kwaad en dat lyding nie van Hom afkomstig is nie. Maar daarmee is nie ' $n$ finale oordeel gevel oor sy boek nie. In die boek draai hy heeltemal tereg die beskouings nek om dat God mense pla en treiter met lyding tot hulle beswil, of dat mense ly omdat hulle dit verdien, of dat God ons dierbares na Hom toe ontruk omdat hulle by Hom 'n beter lewe kan geniet. Wanneer hy dus sê: 'I can worship a God who hates suffering but cannot eliminate it, more easily than I can worship a God who chooses to make children suffer and die, for whatever exalted reason' (Kushner 1982:141) wil 'n mens dit met jou hele wese beaam. In ons dag het dit voorwaar moeilik geword om die belydenis van God se voorsienigheid soos vervat in die Heidelbergse Kategismus (Sondag 10) te beaam. Dit klink net te simplisties om te bely 'dat lower en gras, reën en droogte, vrugbare en onvrugbare jare, spys en drank, gesondheid en krankheid, rykdom en armoede en 
alle dinge nie by toeval nie, maar uit sy vaderlike hand tot ons kom.' Hierdie belydenis help, na my mening, nie mense om hulle lyding sinvol te verwerk nie, maar gee eerder aanleiding tot ' $n$ apatiese berusting (Fiddes 1988:108). Dit was maklik om in die sestiende eeu (v6ór die industriële revolusie) te sê dat 'rykdom en armoede en alle dinge nie by toeval nie, maar uit sy vaderlike hand tot ons kom', want mense het vanaf hulle geboorte-uur tot 'n bepaalde stand behoort. "n Slaaf het slawekinders wat slawe bly, of hulle deugsaam is of nie. 'n Aristokraat het aristokratiese kinders wat ryk erf en in gesagsposisies sal bly, of hulle deugsaam is of nie' (König 1993:26). Mettertyd het die verskillende stande verdwyn en kort voor lank was dit duidelik dat armoede nie 'uit sy vaderlike hand tot ons kom nie', maar via die ekonomiese en politieke sisteme wat mense ontwerp en met mag en geweld in stand hou. Dit is volkome verstaanbaar dat die beskouing dat God soms magteloos staan teenoor die kwaad en met mense en die skepping meely, besig is om veld te wen. Hierdie siening is vir baie mense wat worstel om gelowig te bly te midde van soveel pyn en ellende in ons werreld meer tot troos en hulp as die tradisionele siening van God se almag, impassibiliteit en voorsienigheid ${ }^{8}$. Alhoewel Kushner nie soveel klem lê op die moontlikheid dat God kan ly en inderdaad met mense meely nie, speel dié gedagte tog 'n rol in sy boek (vgl o a Kushner 1982:92-93, 140, 149). $\mathrm{Na}$ my mening kan 'n mens nie oor die magteloosheid (weerloosheid) van God praat los van sy lyding of omgekeerd nie.

\section{DIE LYDENDE GOD}

Die gedagte dat God kan ly, dit wil sê dat Hy nie onbetrokke, onsensitief en apaties is nie, is nie so oud soos die berge nie. In die vroeë kerk is algemeen aanvaar dat God impassibel is, dit wil sê dat gebeure wat buite Hom plaasvind, nie sy innerlike lewe of gevoel kan beïnvloed of dat $\mathrm{Hy} \mathrm{Hom} \mathrm{daardeur} \mathrm{laat} \mathrm{beïnvloed} \mathrm{nie} \mathrm{(vgl} \mathrm{König}$ 1982:56). Die bevraagtekening van hierdie leerstuk (die impassibiliteit van God) het teen die einde van die vorige eeu en aan die begin van hierdie eeu in Brittanje na vore gekom (Sarot 1989:197). Hierdie tendens in die publikasies van Britse teoloë is verder versterk deur die Eerste Wêreldoorlog (Goetz 1986:387), en het eers na vore begin tree in die publikasies van nie-Britse teoloë ná die Tweede Wêreldoorlog. Die onbeskryflike lyding van mense in die Duitse konsentrasiekampe en van die oorlewendes na die kernbomaanval op Hirosjima en Nagasaki het teoloë dwarsoor die wêreld tot 'n herbesinning gedwing van die leerstuk van God se impassibiliteit (vgl Sarot 1989:197; 1990:35).

Marcel Sarot (1990:47-50) wys egter daarop dat daar 'n terminologiese verwarring onder teoloë heers wanneer hulle oor die lyding van God skryf. Die term teopaschitisme behoort volgens hom nie gebruik te word om die posisie van teoloë 
wat hedendaags voorstanders is van die gedagte dat God kan ly, te tipeer nie. Adrio König (1982) en Ronald Goetz (1986) maak hulle onder andere skuldig hieraan. Die teopaschitische formule wat tydens die vyfde ekumeniese konsilie (Konstantinopel $553 \mathrm{n} \mathrm{C}$ ) aanvaar is, wil alleen maar sê dat Jesus Christus (die Middelaar, die geünkarneerde tweede Persoon van die Drie-eenheid) gely het. Hiermee word nie bely dat God (ongekwalifiseerd) gely het nie, ook nie dat Christus na sy goddelike natuur gely het nie. Ons behoort volgens hom liefs te praat van teoloë wat voorstanders is van die gedagte dat God passibel is.

Om presies te kan sê wat ' $n$ mens bedoel met die stelling dat God kan ly en met ons meely, is nie so maklik nie. Allereers kan 'n mens wel sê dat 'sy lyding meer is as 'n "toemaar, Ek ly ook"' (Du Toit 1990:7). Dit is sekerlik waar dat Hy nie fisiese pyn soos ons kan beleef nie, maar dat Hy psigiese pyn (lyding) kan beleef, juis omdat Hy 'n liefdevolle God is, lyk my bo verdenking. Wie bely dat God liefde is, maar Hom lyding wil ontsê, is inkonsekwent, want liefde beteken juis om jou oop te stel vir ander mense en om jou hulle omstandighede aan te trek en jou oor hulle te ontferm. Paul Fiddes (1988:16-45) identifiseer tereg ons belydenis van ' $n$ liefdevolle God as een van die faktore wat aanleiding gegee het tot die groeiende besef dat God kan ly. Ander faktore wat hy nog identifiseer, is die stenwe van Christus aan die knuis, die probleem van menslike lyding en die siening dat God betrokke is by die groei en ontwikkeling van die skepping (vgl ook Steen 1988).

Wanneer ons egter praat oor God se lyding, is dit belangrik om vas te hou aan die gedagte dat God nie 'geïmmobiliseer' word deur lyding nie. Fiddes sê heel tereg: 'If it is essential that a God who helps us should sympathize with our suffering, it is also essential that he should not be overcome or defeated by suffering' (Fiddes 1988:100). Lyding maak God nie magteloos in die sin dat Hy niks kan doen nie. God bly te midde van sy lyding nog steeds God. Sy magteloosheid beteken nie totale onmag nie. Wanneer God ly omdat Hy met ons meely, is Hy anders as die treurende oupa wat uitroep: 'My kinders! Ag, my kinders!' Hy ly met ons mee en help ons om die gebeure te verwerk.

\section{HOE PREEK EN TEOLOGISEER ONS?}

Binne die gereformeerde tradisie word die stelling dikwels gemaak dat predikante nie moet preek na aanleiding van 'n Bybelteks nie, maar die teks moet preek. Voorts word dit ook as 'n vereiste gestel dat wanneer persone teologiseer, hulle dit $B y$ belgetrou moet doen. Met 'Bybelgetrou' word dan bedoel dat teoloë ten minste 'n teks moet kan verskaf op grond waarvan hulle 'n bepaalde (teologiese) stelling maak. 
Wanneer 'n mens egter dieper nadink hieroor duik daar 'n aantal dinge op wat hierdie stellings problematiseer. Eerstens moet ons in ag neem dat ons in die Bybel te doen het met boeke wat nie almal in dieselfde eeu geskryf is nie. Hierdie boeke weerspieël bepaalde ontwikkelinge in mense se denke oor God. Sharkansky (1993: 4) stel dit so: 'The Israelites seem to have changed their conception of God from one period to another.' In die Protestantse tradisie word daar soms gepraat van 'n voortgaande openbaring van God (vgl Rogerson 1982), maar na my mening is dit meer korrek om te praat van ' $n$ voortgesette nadenke oor Hom. Hierdie nadenke het nie op 'n stadium gestop nie. Die teologiese diskussies in die vroeë kerk oor die goddelikheid van Jesus Christus en oor die kwessie of God die Vader ook gely het (patripassianisme) met die sterwe van sy Seun aan die kruis, is voorbeelde hiervan. Die huidige diskussies oor dic passibiliteit van God is ' $n$ ander voorbeeld. Dit is tans moeilik om te praat van die Bybelse siening van God - so asof die Bybel slegs maar eén siening van God weerspieël.

- Tweedens moet ons in ag neem dat die oorspronklike skrywer se siening van God kon verskil van sy lesers s'n. Deur middel van sy geskrif wil hy juis hulle denke oor God beïnvloed en in lyn bring met hoe hy meen daar oor God gedink moet word en hoe hulle hulle godsdiens behoort te beoefen. Dit geld nie net van die profeteboeke nie (vgl Negenman 1975:123), maar ook van ander Bybelboeke. Die boek Job is hiervan 'n goeie voorbeeld. Die skrywer wou met hierdie geskrif die populère verklarings vir lyding waarmee die lesers bekend was, bevraagteken. Deur middel van die verhaal en die gesprekke tussen Job en sy vriende asook tussen Job en God bring hy hulle tot ander insigte. Diagrammaties sou ons dit so kon voorstel:

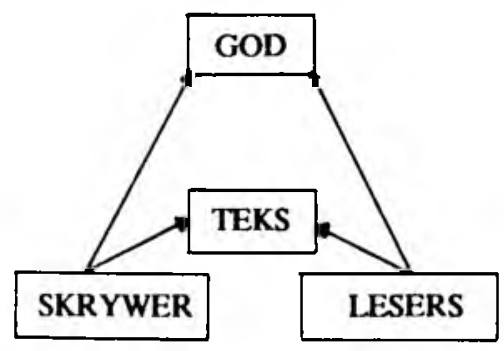

Derdens moet ons ook daarmee rekening hou dat ons godsbeskouing op sy beurt weer ingrypend verskil van die oorspronklike skrywer en lesers s'n. As twintigste eeuse Christene verskil ons godsbeskouing aansienlik van dié van die Israeliete/Jode wat vór Jesus Christus geleef het. Die Ou-Testamentiese mense het nie in 'n 
drie-enige God geglo nie. Vir hulle was daar net één God, naamlik Jahwe9. Selfs die historiese Jesus se godsbeskouing het aansienlik verskil van die Christene van die vierde en vyfde eeu n C s'n (Vermes 1993:208-215). Met die ontstaan en groei van die Christendom het die gedagte van 'n drie-enige God na vore getree en dit het later uitdrukking gevind in belydenisse soos die Apostoliese Geloofsbelydenis en die Geloofsbelydenis van Nicea.

Vierdens moet ons in ag neem dat die Bybel nie aan ons finale teologiese stellinge bied nie, maar impulse vir ons nadenke oor God. Ons hoef dus nie naarstig na Bybeltekste te gaan soek om oor God se lyding te kan praat nie. Dit is wel waar dat daar Ou-Testamentiese tekste is wat daarvan gewag maak dat God bedroef kan word (Gen 6:6); dat Hy onteld kan raak (Hos 11:8); dat Hy berou kan kry oor wat Hy gedoen het (1 Sam 15:11), maar die mense wat vir hierdie tekste verantwoordelik was, het nie soos ons besin oor God en lyding nie. Hierdie tekste kan wel dien as impulse vir ons nadenke oor God en lyding (vgl Jacob 1983), omdat hulle daarvan gewag maak dat God emosies kan beleef, maar self weerspieël hulle nie 'n sistematiese nadenke oor God en lyding nie. Die siening dat God kan ly en inderdaad meely met sy skepping is 'n moderne een wat verband hou met mense se belewenisse in die twintigste eeu. Binne die kulturele milieu van die ou Nabye-Ooste was dit onaanvaarbaar om die stelling te maak dat God magteloos is. ' $n$ Magtelose god is baie gou verruil vir een wat magtiger is. Na my mening weerspieël die stryd tussen die Jahwe- en die Baälpriesters soos weergegee in die Elia-verhale (1 Kon 17-19) en Hosea se veroordeling van die volk se aanbidding van Baäl (soos weerspieël in die boek Hosea) iets hiervan.

Goedhart (1990:62-63) het die kwessie oor hoe ons Bybels moet teologiseer oor God en lyding goed raakgevat met sy opmerking dat die Bybel nie normatief hiervoor is nie. Die Bybel voorsien ons slegs maar van impulse. Die standpunte oor lyding wat ons aantref in die boeke Job en Rut en in die briewe van Paulus en Petrus is nie finale antwoorde op die lydingsvraagstuk nie. Dit is wel belangrike standpunte, maar daarby kan ons dit nie laat nie. Daar was en is ook ander denkers na wie ons moet luister. Denkers soos Dorothee Sölle (1973), Herman Wiersinga (1975), Harold Kushner (1982), Gustavo Gutiérrez (1987) en ander. Goedhart stel dit so:

Dynamisch theologiseren is alleen mogelijk in voortdurend gesprek met de Schrift en met elkaar... Dus: een gelovige visie op God en het lijden, en de theologische reflectie daarop zal nu meer ontwikkeld zijn dan de Schrift aangeeft. Wij zouden het dus nog beter moeten weten dan het boek Job.

(Goedhart 1990:63) 
Paul Fiddes maak 'n soortgelyke opmerking:

Though the Book of Job does not as yet hint at the concept of a suffering God, it does embed a powerful statement about the mystery of suffering within a theophany, thereby pronouncing in no uncertain terms that God is with the sufferer, and leaving the way open for further reflection about the mode of his presence.

(Fiddes 1988:31-32)

Die Bybelboeke is belangrik vir ons as Christene wanneer ons nadink oor God, want dit is die basisdokumente van ons geloof. Hierdie basisdokumente stimuleer ons in ons besinnings oor God (vgl Snyman 1992:84-85), maar dit mag nooit remmend op ons denke inwerk in die sin dat dit ons nie toelaat om verder oor God en lyding na te dink nie. Dit geld eweneens van ons tradisie. Die Gereformeerde tradisie le ons sekere beperkings op, maar dit mag ons nooit verhinder om nuwer weē te ondersoek nie. Ons moet onthou dat die Drie Formuliere vir Eenheid ook histories bepaald is. Hierdie belydenisskrifte werspieël grootliks die teologiese denke van Protestantse teoloë van die sestiende en sewentiende eeu. Ons daarenteen, leef in die twintigste eeu en ons konteks vereis dat ons ons geloof só sal formuleer sodat dit vir mense wat in die twintigste eeu leef, sin maak, troos bied en hoop gee.

\section{ENDNOTAS}

1. Die boek is oorspronklik in 1981 gepubliseer.

2. Afgesien daarvan dat die boek 'n onaantreklike titel het, laat die Afrikaanse vertaling veel te wense oor. Die boek moes in 'n meer alledaagse idioom vertaal gewees het. Dit is een van die redes waarom dit nie ook in Afrikaans 'n blitsverkoper geword het soos in die geval van die Nederlandse vertaling $A l s$ ' kwaad goede mensen treft nie. Volgens Havinga (1988:7) het die Nederlandse vertaling al twee-en-twintig herdrukke beleef wat beteken dat ongeveer 110000 Nederlanders die boek besit.

3. Daniel Foley (1988) onderskei nie minder nie as elf populêre verklarings vir persoonlike lyding.

4. Loader (1993:10) se stelling dat ons gebeurtenisse in 'n wyer perspektief moet sien (dat die uitdunning van die mensdom tydens oorloë, net soos virusse, siekte en dood sin maak) is 'n voorbeeld van hierdie tipe interpretasie.

5. Die Afrikaanse Bybelvertaling se numerering van die verse in die Jahweredes loop nie parallel met die Hebreeuse teks (Biblia Hebraica Stuttgantensia) s'n nie. In die Afrikaanse vertaling is dit Job 40:4-9. 
6. In die Afrikaanse vertaling (Job 40:20) is die Hebreeuse woord (Liwyatan - Job 40:25) met 'krokodil' vertaal, maar dit is 'n mitologiese seemonster waarna verwys word.

7. Albei die Jahweredes begin met die woorde: 'Toe antwoord Jahwe Job uit 'n storm', tenwyl die frase 'Omgord jou heupe soos 'n man; Ek sal jou vra en antwoord jy My' ook herhaal word. Die Jahweredes bestaan verder uit twee duidelik onderskeibare dele (vgl Habel 1985:526-527).

8. Willem Nicol (1992a) en Adrio König (1992) probeer elkeen op hul eie wyse wegkom van die argaïese formulering van God se betrokkenheid by gebeure in hierdie wêreld en dit is betreurenswaardig dat dreigemente van kerklike tug by die gesprek ingesleep is (vgl Scholtz 1992).

9. Met hierdie stelling wil ek nie beweer dat die Israelitiese godsdiens sedert die tyd van Abraham monoteisties was nie. Suiwer monoteïsme was na alle waarskynlikheid 'n laat ontwikkeling in die godsdiens van Israel (vgl Boshoff 1988).

\section{Literatuurverwysings}

Blank, S H 1955. 'Doest thou well to be angry?': A study in self-pity. HUCA 26, 29-41.

Boshoff, W S 1988. Die monoteissme: Vroeë rigtinggewer of laat aankomeling in die godsdiensgeskiedenis van Israel? $T h E v(S A)$ 21/3, 2-14.

Brenner, A 1981. God's answer to Job. VT 31, 129-137.

Cooper, B 1991. When modern consciousness happens to good people: Revisiting Harold Kushner. ThTo 48, 290-300.

Du Toit, C 1990. 'n Teologiese perspektief op lyding, in Vos \& Müller 1990:1-10.

Fiddes, P S 1988. The creative suffering of God. Oxford: Clarendon.

Foley, D P 1988. Eleven interpretations of personal suffering. JRHe 27, 321-328.

Goedhart, G L 1990. Met Job meer mens: Job - pastoraat - Kushner, in Jagersma, H (red), Job: Studies over en rondom een bijbelboek, 56-63. Kampen: Kok.

Goetz, R 1986. The suffering God: The rise of a new orthodoxy. CCen 103, 385389.

Gutiérreż, G 1987. On Job: God-talk and the suffering of the innocent. New York: Orbis.

Habel, N C 1985. The Book of Job: A commentary. London: SCM. (OTL.) Häring, H 1987. Waar is God dan nog goed voor? Over Kushners boek Als 't kwaad goede mensen treft. Wend 42, 243-251. 
Havinga, D 1988. God helpt wie zichzelf helpt: Het boek van H S Kushner: $A l s$ 't kwaad goede mensen treft in Brochures Theologie \& Maatschappij, Onschuldig lijden en spreken over God, 7-12. Utrecht: Vereniging voor Theologie en Maatschappij. (Brochure 3.)

Jacob, E 1983. Le Dieu souffrant: Un thème théologique vétérotestamentaire. ZAW 95, 1-8.

König, A 1982. The idea of 'the crucified God': Some systematic questions. JTSA 39, 55-61.

— 1992. Beheer, of stryd en oorwinning? Die Kerkbode, 23 Oktober, bl 10.

- 1993. Menslike mense. Halfway House: Orion. (Gelowige nagedink 5: Oor die mens en die sonde in die praktyk.)

Küng, H 1992. The religious situation of our time: Judaism. London: SCM.

Kushner, H S 1982. When bad things happen to good people. London: Pan Books.

- 1983a. Als 't kwaad goede mensen treft. Ten Have: Baarn.

- 1983b. My ongelukskind. Kaapstad: Tafelberg.

Lambrecht, J (red) 1988. Hoelang nog en waarom toch? God, mens en lijden. Leuven: Acco.

Loader, J A 1983. Job: Antwoord of enigma? $T h E v(S A)$ 16/2, 15-31.

- 1993. 'n Mee-lydende God: Antwoord aan lesers wat meen Hy verloor beheer. Beeld, 21 Januarie, bl 10.

Marcus, R 1949. Job and God. RR 17, 5-29.

Müller, H-P 1978. Das Hiobproblem: Seine Stellung und Entstehung im Alten Orient und im Alten Testament. Darmstadt: WBG. (EdF 84.)

Negenman, J 1975. Het interpreteren van de prophetische literatuur. TTh 15, 117 140.

Nicol, W 1992a. Is God Albeskikker? Sy beheer nog 'oppad' om volle werklikheid te word. Beeld, 27 Oktober, bl 10.

- 1992b. Bewerk God alle gebeure? Beeld, 17 November, bl 9.

Rogerson, J W 1982. Progressive revelation: Its history and its value as a key to Old Testament interpretation. EpRe 9, 73-86.

Rowley, H H 1970. Job London: Nelson. (NCeB.)

Sarot, M 1989. De passibilitas Dei in de hedendaagse Westerse theologie. KeTh 40, 196-206.

- 1990. Het lijden van God? Enkele terminologische notities bij een hedendaagse theologische discussie. NedThT 44, 35-50.

Schillebeeckx, E 1987. Overwegingen rond Gods 'weerlose overmacht'. TTh 27, 370-381.

Scholtz, A 1992. Brief in Beeld, 3 November. 
Sharkansky, I 1993. The several faces of God in the Hebrew Bible: A political analysis. Myth \& Symbol 1, 3-28.

Snyman, G F 1992. The Old Testament: An absurd fossil or a pool in the great sea of stories?, in Wessels, W \& Scheffler, E (eds), Old Testament science and reality: A mosaic for Deist, 70-88. Pretoria: Verba Vitae.

Sölle, D 1973. Lijden. Baarn: Bosch \& Keuning.

Steen, M 1988. Het actuele thema van de 'lijdende' God: Een terreinverkenning, in Lambrecht 1988:75-107.

Tsevat, M 1980. The meaning of the book of Job, in The meaning of the book of Job and other biblical studies, 1-37. New York: Ktav.

Vanhoutte, J 1988. Een thematisch overzicht van de recente literatuur over 'God en het lijden', in Lambrecht 1988:261-286.

Vermes, G 1993. The religion of Jesus the Jew. Minneapolis: Fortress.

Vos, C J A \& Müller, J C (red) 1990. God in ons lyding. Pretoria: Orion. (God, mens en wêreld.)

Wiersinga, H 1975. Verzoening met het lijden? Baarn: Ten Have. 